\title{
The Effect of Clinical, Laboratory Findings and Parenchymal Infiltration Features on the Diameter of the Main Pulmonary Artery in COVID-19 Pneumonia
}

\author{
Deniz Esin Tekcan Şanlı ${ }^{1,2}$ iD
}

'Department of Radiology, Acibadem Kozyatagi Hospital, Istanbul, Turkey

${ }^{2}$ Department of Medical Imaging Techniques, Vocational School of Heatlh Services, Istanbul Rumeli University, Istanbul, Turkey

Deniz Esin TEKCAN ŞANLI

Correspondence: Deniz Esin Tekcan Şanl Department of Radiology, Acibadem Kozyatagi Hospital, Istanbul, Turkey

Phone: +905448104446

E-mail: tekcandenizesin@acibadem.com

Received: 1 May 2021

Accepted: 8 January 2022

\begin{abstract}
Purpose: The main pulmonary artery diameter is an indirect indicator of the pulmonary vascular bed resistance. In this study, it was aimed to reveal the parameters that are associated with respiratory distress by evaluating the parameters affecting the diameter of the main pulmonary artery in patients diagnosed with COVID-19 pneumonia.

Methods: The relationship the presence of a comorbidity, clinical findings, laboratory values, pulmonary infiltration features, and main pulmonary artery diameter (MPAD) was statistically evaluated.

Results: When MPAD $27.5 \mathrm{~mm}$ was considered as enlargement; it was significantly wider in smokers in COVID-19 pneumonia $(p<0.05)$. It was statistically shown that there was no association with diabetes, hypertension, asthma, or COPD and MPAD $(p>0.05)$. It was observed that MPAD was associated with shortness of breath $(p=0.039 ; p<0.05)$ but not with cough and fever $(p>0.05)$. Also, it was found that MPAD was significantly wider in cases with high CRP and LDH values $(p=0.008 ; p<0.01, p=0.011 ; p<0.05$, respectively). While MPAD did not differ significantly in those with ground-glass infiltration; MPAD was significantly larger in those with infiltration in the form of crazy-paving or consolidation $(p<0.05)$. While there was no significant variation in MPAD in those with periferobasal involvement; MPAD was significantly wider in cases with central or mixed infiltration $(p<0.05)$.
\end{abstract}

Conclusion: It is possible to indirectly predict respiratory distress in COVID-19 patients by measuring MPAD, which is associated with respiratory distress. CRP and LDH values, central infiltration in the pattern of crazy-paving or consolidation are related with increased MPAD in COVID-19 pneumonia.

Keywords: COVID-19, SARS-CoV-2, respiratory distress, main pulmonary artery diameter, chest CT, crazy-paving, groundglass opacity

COVID-19 Pnömonisinde Klinik, Laboratuvar Bulguları ve Parankimal İnfiltrasyon Özelliklerinin Ana Pulmoner Arter Çapına Etkisi

ÖZET

Amaç: Ana pulmoner arter çapı, pulmoner vasküler yatak direncinin dolaylı bir göstergesidir. Bu çalışmada COVID-19 pnömonili olgularda ana pulmoner arter çapını etkileyen parametreler değerlendirilerek solunum distresi ile hangi parametrelerin ilişkili olduğunu ortaya çıkarmak amaçlanmıştır.

Yöntem: Komorbid hastalıklar, klinik bulgular, laboratuvar değerleri, pulmoner infiltrasyon özellikleri ve ana pulmoner arter çapı (APAÇ) arasındaki ilişki istatistiksel olarak değerlendirildi.

Bulgular: $A P A C ̧>27,5$ mm genişleme olarak kabul edildiğinde; COVID-19 pnömonisinde APAÇ sigara içenlerde anlamlı olarak daha genişti $(p<0.05)$. Diyabet, hipertansiyon, astım veya KOAH ile APAÇ arasında anlamlı ilişki saptanmadı ( $p>0.05)$. APAÇ'ın nefes darlığı ile ilişkili olduğu $(p=0,039 ; p<0,05)$ ancak öksürük ve ateşle ilişkili olmadığı $(p>0,05)$ görüldü̈. Ayrıca CRP ve LDH değerleri yüksek olan olgularda APAÇ'ın anlamlı olarak daha geniş olduğu saptandı (sırasılyla $p=0,008 ; p<0,01, p=0,011 ; p<0,05)$. APAÇ, buzlu cam formunda parankimal infiltrasyonu olanlarda anlamlı farklılık göstermezken; crazy-paving (kaldırım taşı) veya konsolidasyon şeklinde infiltrasyonu olanlarda APAÇ anlamlı olarak daha genişti $(p<0.05)$. Periferobazal dağılım gösteren infiltrasyonu olanlarda APAÇ'ta anlamlı bir artış olmamakla birlikte; santral ve yaygın infiltrasyonu olan olgularda APAÇ anlamlı olarak daha genişti $(p<0.05)$.

Sonuç: Solunum distresi ile ilişkili olan APAÇ ölçülerek, COVID-19 pnömonili olgularda solunum distresini dolaylı yoldan radyolojik olarak tahmin etmek mümkündür. COVID-19 pnömonisinde CRP ve LDH değerleri, crazy-paving veya konsolidasyon paterninde santral ve yaygın infiltrasyon artmış APAÇ ile ilişkilidir.

Anahtar Kelimeler: COVID-19, SARS-CoV-2, solunum distresi, ana pulmoner arter çapı, toraks BT, crazy-paving, buzlu 
T he pandemic caused by the SARS-CoV-2 virus has infected 236 million people as of April 2021, causing 4.8 million deaths worldwide (1). The clinical symptoms are severe and a result of diffuse alveolar damage caused by affecting the lower respiratory tract (2). Respiratory distress is a common cause of death in patients infected with the virus $(2,3)$. However, alveolar damage and impaired pulmonary oxygenation are responsible for the respiratory distress experienced in many patients with severe disease $(2,3)$. In this retrospective study, we evaluated the parameters that were associated with the increase in main pulmonary artery diameter (MPAD), which is an indirect indicator of the resistance created by the impaired ventilation / perfusion balance in the pulmonary vascular bed in COVID-19 pneumonia cases. Thus, we aimed to predict whether the patient will have respiratory distress by looking at the diameter of MPAD in patients diagnosed with COVID-19 pneumonia, and to help clinicians in terms of early treatment or hospitalization.

\section{MATERIAL AND METHODS}

Local institutional review board approval was obtained for this retrospective study (2020-05/28), and informed consent forms were obtained before $\mathrm{CT}$ acquisition.

Study population: The study was performed retrospectively by evaluating the images of patients who applied to our clinic with suspected COVID-19 and underwent lowdose non-contrasted chest computerized tomography (CT) between March 2020-March 2021.

Inclusion criteria: Cases with radiologically or PCR-proven COVID-19 infection and CT performed in our hospital due to COVID-19 were included in the study.

Exclusion criteria: Patients with widespread organizing pneumonia or adult respiratory distress syndrome (ARDS) pattern, patients with pleural effusion, suspicious lung mass for malignancy, previous lung operation history, pulmonary thromboembolism, patients receiving radiotherapy to the chest area, and patients with a history of rheumatologic disease were excluded from the study.

Imaging methods: All CT scans were done with Siemens Somatom Sensation-Syngo CT 2009 device using a lowdose non-contrast CT protocol. Patients were scanned in the supine position during deep inspiration. The acquisition parameters were standardized as; tube voltage: 140 $\mathrm{kV}$, tube current:40 mA, pitch:1,4, FOV:455 mm, slice thickness: $64 \times 0,6 \mathrm{~mm}$. The isolation rules were applied during and after the scanning had complied. All measurements were calculated by an experienced radiologist in chest CT.

Image analysis: The main pulmonary artery diameter (MPAD) of SARS-CoV-2 PCR (+) cases admitted to the hospital were measured by a radiologist experienced in chest $\mathrm{CT}$ with standardized measurement locations and techniques. MPAD whether equal and above $27.5 \mathrm{~mm}$ was accepted as enlargement (4). The patient's chronic diseases (diabetes, hypertension, asthma, chronic obstructive pulmonary disease (COPD), other diseases), smoking history, patient's laboratory parameters (lymphocyte count, Neutrophil / Lymphocyte ratio (N/L), D-Dimer, lactate dehydrogenase (LDH), Ferritin, Procalcitonin), dominant symptoms (high fever, shortness of breath/dyspnea, cough), lung parenchyma infiltration features (dominant infiltration pattern:ground-glass opacity, crazy-paving or consolidation, involved lobe, distribution of involvement: periferobasal, central or mixed) due to COVID-19 pneumonia was statistically evaluated according to the MPAD variability. It was evaluated that which variables associated with MPAD in the study.

Measurement methods: In the study, the MPAD were measured in all cases. The widest diameter perpendicular to the long axis of the MPAD was measured with computer calipers at the level of the pulmonary artery (PA) bifurcation. (Figure 1) (5).

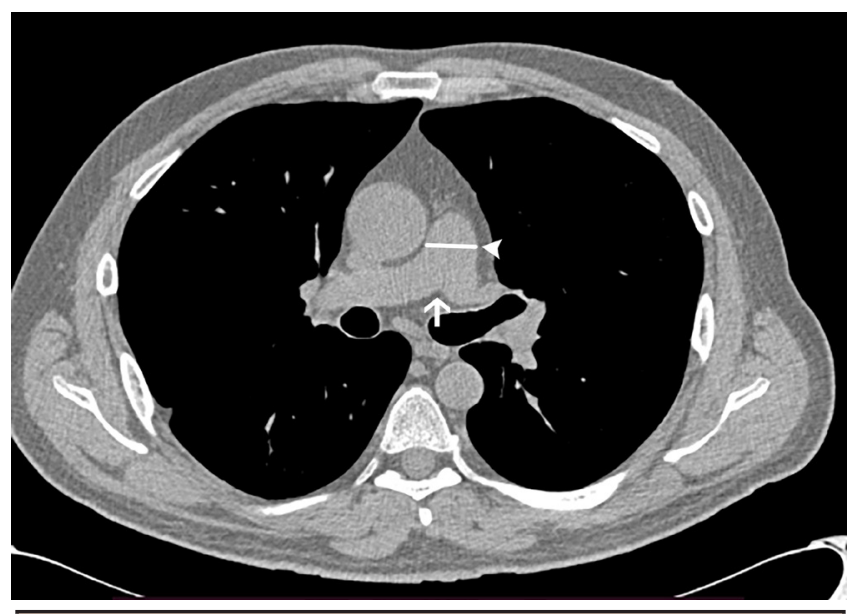

Figure 1. Demonstration of MPAD's measurement method. The widest diameter perpendicular to the long axis of the MPAD (arrow head) was measured with computer calipers at the level of the pulmonary artery (PA) bifurcation (arrow). 
Statistical analysis: Statistical analysis: NCSS (Number Cruncher Statistical System) 2007 (Kaysville, Utah, USA) program was used for statistical analysis. While evaluating the study data, besides descriptive statistical methods (mean, standard deviation, median, frequency, ratio, minimum, maximum), Pearson chi-square test, Fisher's Exact test and Fisher Freeman Halton test were used for comparison of qualitative data. Significance was evaluated at $p$ $<0.05$ levels.

\section{RESULTS}

A total of 102 cases were included in the study. Of these 102 cases, $71.6 \%(n=73)$ were male, $28.4 \%(n=29)$ were female, and the mean age was $48.62 \pm 14.42$ (19-94). The rates of diabetes, hypertension, asthma, COPD, and other diseases did not show significant difference according to the presence of MPAD enlargement ( $p>0.05)$. The smoking rate was found to be significantly higher in patients with enlargement of the MPAD compared to those without $(p=0.044 ; p<0.05)$ (Table 1$)$. The odds ratio of MPAD enlargement in smokers was 3,500 times more compared to nonsmokers (Cl 95\%:1,138-10,764). When the relationship between symptoms and MPAD was evaluated; there was no significant relationship between fever and cough with MPAD ( $p>0.05$ ). However, MPAD was found to be significantly wider in patients with dyspnea $(p=0.039 ; p<0.05)$ (Table 1).

Table 1: Relationship between MPAD enlargement and comorbid diseases /symptoms

\begin{tabular}{|c|c|c|c|}
\hline & \multicolumn{2}{|c|}{ MPAD enlargement } & \multirow{2}{*}{$\mathbf{p}$} \\
\hline & $(+) \geq 27.5 \mathrm{~mm}$ & $(-)<27.5 \mathrm{~mm}$ & \\
\hline $\begin{array}{l}\text { Diabetes } \\
\text { mellitus }\end{array}$ & $3(16.7)$ & $9(10.7)$ & b 0.440 \\
\hline Hypertension & $4(22.2)$ & $16(19.0)$ & '0.749 \\
\hline Asthma & $1(5.6)$ & $3(3.6)$ & ${ }^{b} 0.546$ \\
\hline COPD & $0(0.0)$ & $10(11.9)$ & b0.202 \\
\hline Smoking & $7(41.2)$ & $14(16.7)$ & b0.044* \\
\hline $\begin{array}{l}\text { Other } \\
\text { Diseases }\end{array}$ & $2(11.1)$ & $2(2.4)$ & b 0.142 \\
\hline Fever & $12(66.7)$ & $35(41.7)$ & ${ }^{\mathrm{a}} 0.053$ \\
\hline Dyspnea & $7(38.9)$ & $12(14.3)$ & b0.039* \\
\hline Cough & $16(88.9)$ & $56(66.7)$ & ${ }^{\mathrm{a}} 0.060$ \\
\hline \multicolumn{4}{|c|}{${ }^{\circ}$ Fisher'sExact Test $\quad{ }^{*} p<0.05$} \\
\hline
\end{tabular}

When the relationship between laboratory findings and MPAD enlargement was evaluated, no statistically significant difference was found between low lymphocytes count and N/L ratio over 3 ( $p>0.05$ ). No statistically significant difference was found between D-dimer, Ferritin and Procalcitonin and the enlargement of MPAD ( $p>0.05)$. In patients with MPAD enlargement, CRP and LDH values were found to be significantly higher than those without ( $p=0,008 ; p<0,01, p=0,011 ; p<0,05$, respectively) (Table 2 ).

When MPADs were evaluated according to the infiltration pattern and distribution due to COVID-19 pneumonia; it was observed that there was no significant vascular enlargement in patients with ground-glass infiltration ( $p>0.05)$, but it was significantly enlarged in patients with infiltration in the form of crazy-paving or consolidation $(p=0.003 ; p<0.01)$. While MPAD was enlarged in patients with right middle lobe and left upper lobe involvement, no statistically significant difference was found in the case of infiltration of other lobes $(p=0,017 ; p<0,05, p=0,029$; $p<0,05, p>0,05$, respectively) (Figure 2) (Table 3).

\section{DISCUSSION}

It is known that the SARS-CoV-2 virus enters the cell by binding to the angiotensin converting enzyme-2 (ACE-2) receptors on the cell surface (6). Since the respiratory tract epithelium is rich with ACE receptors, especially upper respiratory system involvement is observed in the majority of patients (2). In case of underlying facilitating factors such as advanced age, presence of a comorbid disease, immunodeficiency, the cellular damage caused by the virus also increases (7). This situation appears as diffuse alveolar damage in the lungs that can be radiologically visualized as ground-glass opacity, which turns into a cobblestone (crazy-paving) or consolidation pattern in advanced stages (8). In case of severe destruction of the alveoli, the alveolar oxygenation disruption also causes vasoconstriction in the pulmonary vascular bed with the effect of local inflammatory cytokines $(2,9)$. It may cause an increase in the pressure of the intrapulmonary arteries, leading to dilatation in the diameter of the main pulmonary artery. Ventilation to perfusion balance is also disturbed, reducing blood oxygenation (10). Clinically, it causes complaints of dyspnea and respiratory distress in patients that may require oxygen support. In this study, the relationship between clinical, laboratory, and radiological findings in COVID-19 pneumonia and pulmonary artery diameter was evaluated, and whether it was associated with possible virus-related pulmonary hypertension and respiratory distress experienced in the disease. According to the study, it was observed that MPAD was significantly wider in smokers and patients with dyspnea, patients with high CRP and LDH values, and cases with central or widespread involvement in the form of crazy-paving or consolidation. 


\begin{tabular}{|c|c|c|c|c|}
\hline & & \multicolumn{2}{|c|}{ MPAD enlargement } & \multirow{2}{*}{$\mathbf{P}$} \\
\hline & & $(+) \geq 27.5 \mathrm{~mm}$ & $(-)<27.5 \mathrm{~mm}$ & \\
\hline Lymphopenia $10 \wedge 3 / u L$ & $(1.3-3.76)$ & $9(50.0)$ & $22(41.5)$ & ${ }^{\mathrm{a}} 0.530$ \\
\hline High N/L & $>3$ & $8(47.1)$ & $18(34.0)$ & ${ }^{\mathrm{a}} 0.331$ \\
\hline \multirow{2}{*}{ CRP $(<0.5) \mathrm{mg} / \mathrm{dL}$} & Normal & $1(5.9)$ & $20(40.8)$ & \multirow{2}{*}{ a $0.008 * *$} \\
\hline & High & $16(94.1)$ & $29(59.2)$ & \\
\hline \multirow{2}{*}{ D-dimer $(<0.5) \mathrm{mg} / \mathrm{L}$} & Normal & $3(30.0)$ & $2(12.5)$ & \multirow{2}{*}{ b0.340 } \\
\hline & High & $7(70.0)$ & $14(87.5)$ & \\
\hline \multirow{2}{*}{ LDH (120-246) IU/L } & Normal & $9(50.0)$ & $69(82.1)$ & \multirow{2}{*}{${ }^{b} 0.011 *$} \\
\hline & High & $9(50.0)$ & $15(17.9)$ & \\
\hline \multirow{2}{*}{ Ferritin $(10$ - 291) ng/L } & Normal & $0(0.0)$ & $5(26.3)$ & \multirow{2}{*}{ b0.128 } \\
\hline & High & $12(100.0)$ & $14(73.7)$ & \\
\hline \multirow{2}{*}{ Procalsitonin $(<0.15) \mathrm{ng} / \mathrm{mL}$} & Normal & $4(40.0)$ & $5(26.3)$ & \multirow{2}{*}{ b0.675 } \\
\hline & High & $6(60.0)$ & $14(73.7)$ & \\
\hline aPearsonChi-Square Test & & $* *_{p}$ & & \\
\hline
\end{tabular}

\begin{tabular}{|c|c|c|c|c|}
\hline & & \multicolumn{2}{|c|}{ MPAD enlargement } & \multirow{2}{*}{$\mathbf{P}$} \\
\hline & & $(+) \geq 27.5 \mathrm{~mm}$ & $(-)<27.5 \mathrm{~mm}$ & \\
\hline \multicolumn{2}{|c|}{ Ground-Glass opacity } & $18(100.0)$ & $79(94.0)$ & b0.583 \\
\hline \multicolumn{2}{|c|}{ Crazy-paving-Consolidation } & $11(61.1)$ & $21(25.0)$ & ${ }^{\mathrm{a}} 0.003 *$ \\
\hline \multicolumn{2}{|c|}{ Right Upper Lobe } & $14(77.8)$ & $43(54.4)$ & b0.110 \\
\hline \multicolumn{2}{|c|}{ Left Upper Lobe } & $14(77.8)$ & $39(49.4)$ & a0.029* \\
\hline \multicolumn{2}{|c|}{ Right Middle Lobe } & $10(55.6)$ & $21(26.6)$ & ${ }^{\mathrm{a}} 0.017 *$ \\
\hline \multicolumn{2}{|c|}{ Right Lower Lobe } & $17(94.4)$ & $63(79.7)$ & b0.183 \\
\hline \multicolumn{2}{|c|}{ Left Lower Lobe } & $16(88.9)$ & $62(78.5)$ & b0.512 \\
\hline \multirow{2}{*}{ Distrubition } & Peripherobasal & $3(16.7)$ & $39(49.4)$ & ${ }^{\mathrm{a}} 0.212$ \\
\hline & Central- Mixt & $15(83.3)$ & $32(40.5)$ & ${ }^{a} 0.004 * *$ \\
\hline \multicolumn{5}{|c|}{ aPearson Chi-Square Test $\quad$ bFisher'sExact Test } \\
\hline
\end{tabular}

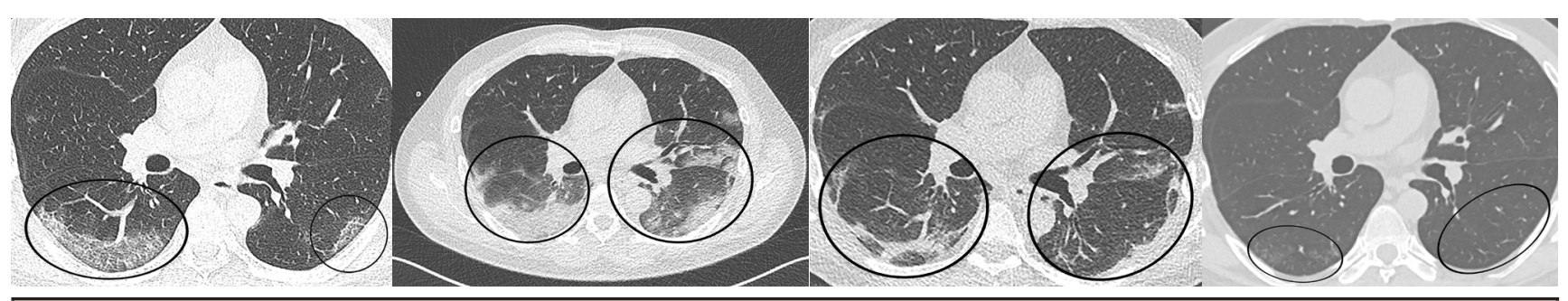

Figure 2. In Fig 2a, infiltration pattern as ground-glass opacities accompanying crazy-paving pattern distributed peripherally (circles) in the both lower lobe is seen (04.11.2020). In $2 \mathrm{~b}$, it is seen that the infiltration pattern turns into consolidation and the infiltration areas (circles) increase in the progression stage of the disease (10.11.2020). In Fig 2c, it is shown that in the regression phase of the disease, infiltration areas have been replaced by fibrotic band formations (circles) (17.11.2020). In Fig $2 \mathrm{~d}$, it is seen that all infiltrations regress almost completely, leaving their place to residual ground glass opacities (circles) (26.01.2020). 
No relationship was found between MPAD and fever, which is one of the main symptoms of the disease.lt can be thought that the inflammatory cytokines such as IL-1 and IL-6, which are primarily responsible for fever, can reduce pulmonary vascular resistance by vasodilator effect and do not cause a significant change in $\operatorname{MPAD}(11,12)$ No relationship was found between MPAD and low lymphocyte count and high N/L ratio, which are considered as pathognomonic laboratory findings of the disease. The reason for this situation may be that the immunological battle with the virus is at the intravascular level rather than the pulmonary interstitial area. However, the relationship between CRP, which is considered as an indicator of the degree of inflammatory warfare in the body, and LDH values, which are indicative of cellular damage, with MPAD indicates that blood oxygenation, pulmonary vascular bed resistance and thus MPAD may be affected as the damage in the body increases (13-17). As in the study of Zhou et al., it has been shown in many studies so far that high LDH levels are associated with respiratory distress and ARDS $(14,15)$.

The change of radiological findings of COVID-19 pneumonia according to the stage of the disease and time has been well described in previous literature studies (8). The most common pattern of virus-related pulmonary involvement is ground-glass opacities with periferobasal distribution. Although transformation into crazy-paving or consolidation pattern is an expected finding in the advanced stages of the disease, it may not occur in young patients and those with mild disease, and these ground-glass opacities may regress spontaneously. In other words, those with involvement in crazy-paving and consolidation pattern have more severe clinical symptoms and respiratory distress. Blood oxygenation is lower in these patients compared to patients with ground-glass infiltration, and oxygen support and even endotracheal intubation are required in most of them (7). The wider MPAD in this pattern and in patients with central or widespread involvement in our study indicates that MPAD is associated with respiratory distress. There are also recent literature studies supporting the results of our study. In the study of Esposito et al., it was shown that enlarged MPAD ( $\geq 31$ $\mathrm{mm}$ ) at admitting chest $\mathrm{CT}$ is an independent predictor of mortality in COVID-19 (18).Yildiz et al. showed that increased main pulmonary artery diameter is associated with poorer prognosis for patients with COVID-19 pneumonia in their study (19).

Our study has some limitations. The most important technical limitation of this retrospective study is the evaluation of a vascular structure on non-contrast examinations. However, achieving high quality of all exams in standard protocols with new generation devices greatly exceeds this limitation. Another limitation of the study is that the parenchymal imaging findings were performed by a single radiologist and the interobserver difference was not evaluated.

As a result; MPAD enlargement is associated with widespread infiltration in the pattern of crazy-paving or consolidation, CRP and LDH parameters, that proportional to the severity of the disease in COVID-19 pneumonia. Measuring MPAD during radiological evaluation will guide clinicians in terms of treatment plan and hospitalization.

\section{DECLARATIONS}

Funding

The author received no financial support for the research, authorship, and/or publication of this article.

\section{Conflicts of interest}

The author declares that there is no conflict of interest

\section{Ethics approval}

The study protocol was approved by local ethics committee (Date: 20.08.2020 No: 2020/18). The study complied with the Declaration of Helsinki.

\section{Availability of data and material}

The materials described in the manuscript will be freely available to any scientist wishing to use them for noncommercial purposes, without breaching participant confidentiality.

\section{Authors' contributions}

Concept - D.E.T.Ş.; Design - D.E.T.Ş.; Supervision - D.E.T.Ş.; Resource - D.E.T.Ş.; Materials - D.E.T.Ş.; Data Collection and/or Processing - D.E.T.Ş.; Analysis and/or Interpretation - D.E.T.Ş.; Literature Search - D.E.T.Ş.; Writing - H.K.K., E.E.A.; Critical Reviews - D.E.T.Ş. 


\section{REFERENCES}

1. WHO Coronavirus (COVID-19) Dashboard https://covid19.who.int/ access date 09.10.2021

2. Batah SS and Fabro AT. Pulmonary pathology of ARDS in COVID-19: A pathological review for clinicians. Respir Med. 2021;176:106239. DOI: 10.1016/j.rmed.2020.106239.

3. van Eijk $L E$, Binkhorst $M$, Bourgonje $A R$, et al. COVID-19: immunopathology, pathophysiological mechanisms, and treatment options. J Pathol. 2021:10.1002/path.5642. DOI: 10.1002/ path.5642.

4. Chen X, Liu K, Wang Z, et al. Computed tomography measurement of pulmonary artery for diagnosis of COPD and its comorbidity pulmonary hypertension. Int J Chron Obstruct Pulmon Dis. 2015;10:2525-33. DOI: 10.2147/COPD.S94211.

5. Truong QA, Massaro JM, Rogers IS, et al. Reference values for normal pulmonary artery dimensions by noncontrast cardiac computed tomography: the Framingham Heart Study. Circ Cardiovasc Imaging. 2012;5:147-54. DOI:10.1161/CIRCIMAGING.111.968610

6. Bhalla V, Blish CA and South AM. A historical perspective on ACE2 in the COVID-19 era. J Hum Hypertens. 2020;1-5. DOI: 10.1038/ s41371-020-00459-3

7. Tekcan Sanli $D E$, Yildirim $D$, Sanli $A N$, et al. Predictive value of $C T$ imaging findings in COVID-19 pneumonia at the time of firstscreen regarding the need for hospitalization or intensive care unit. Diagn Interv Radiol. 2020. DOI: 10.5152/dir.2020.20421.

8. Sanli DET, Yildirim D, Sanli AN, et al. A practical approach to imaging characteristics and standardized reporting of COVID-19: a radiologic review. Mil Med Res. 2021;8:7. DOI: 10.1186/s40779-021-00301-y.

9. Karmouty-Quintana $\mathrm{H}$, Thandavarayan RA, Keller SP, et al. Emerging Mechanisms of Pulmonary Vasoconstriction in SARS-CoV-2Induced Acute Respiratory Distress Syndrome (ARDS) and Potential Therapeutic Targets. Int J Mol Sci. 2020;21:8081. DOI: 10.3390/ ijms21218081.

10. Santamarina MG, Boisier D, Contreras R, et al. COVID-19: a hypothesis regarding the ventilation-perfusion mismatch. Crit Care. 2020;24:395. DOI: 10.1186/s13054-020-03125-9.

11. Peluso L, Abella BS, Ferrer R, et al. Fever management in COVID-19 patients. Minerva Anestesiol. 2021;87:1-3. DOI: 10.23736/ S0375-9393.20.15195-2.

12. Sanli DET, Altundag A, Kandemirli SG, et al. Relationship between disease severity and serum IL-6 levels in COVID-19 anosmia. Am J Otolaryngol. 2021;42:102796. DOI: 10.1016/j.amjoto.2020.102796.

13. Smilowitz NR, Kunichoff D, Garshick M, et al. C-reactive protein and clinical outcomes in patients with COVID-19. Eur Heart J. 2021:ehaa1103. DOI: 10.1093/eurheartj/ehaa1103.

14. Szarpak L, Ruetzler K, Safiejko K, et al. Lactate dehydrogenase level as a COVID-19 severity marker. Am J Emerg Med. 2020:S07356757(20)31034-2. DOI: 10.1016/j.ajem.2020.11.025.

15. Zhou Y, Ding N, Yang G, et al. Serum lactate dehydrogenase level may predict acute respiratory distress syndrome of patients with fever infected by SARS-CoV-2. Ann Transl Med. 2020;8:1118. DOI: 10.21037/atm-20-2411.

16. Henry BM, Aggarwal G, Wong J, et al. Lactate dehydrogenase levels predict coronavirus disease 2019 (COVID-19) severity and mortality: A pooled analysis. Am J Emerg Med. 2020;38(9):1722-6. DOI: 10.1016/j.ajem.2020.05.073.

17. Sanli DET, Yildirim D, Sanli AN, Turkmen S, Erozan N, Husmen G, Altundag A, Tuzuner F. A practical approach to imaging characteristics and standardized reporting of COVID-19: a radiologic review. Mil Med Res. 2021;8(1):7. DOI: 10.1186/ s40779-021-00301-y.
18. Esposito A, Palmisano A, Toselli M, Vignale D, Cereda A, Rancoita PMV, et al. Chest CT-derived pulmonary artery enlargement at the admission predicts overall survival in COVID-19 patients: insight from 1461 consecutivepatients in Italy. Eur Radiol. 2021;31(6):403141. DOI: $10.1007 / \mathrm{s} 00330-020-07622-x$

19. Yildiz M, Yadigar S, Yildiz BŞ, Aladag NB, Keskin O, Ozer RS, Topel C, Kahraman S. Evaluation of the relationship between COVID-19 pneumonia severity and pulmonary artery diameter measurement. Herz. 2021;46(1):56-62. DOI: 10.1007/s00059-020-05014-x. 